\title{
DNA Barcoding of Myrica esculanta (Kafal), An Indigenous, Multipurpose and Medicinal Plant Species from Nepal, by rbcL and matK Gene
}

\author{
Deepak Sharma $^{1 *}$, Tirtha Maiya Shrestha ${ }^{2}$ and Janardan Lamichhane ${ }^{\mathbf{1}}$ \\ ${ }^{1}$ Department of Biotechnology, School of Science, Kathmandu University, Nepal \\ ${ }^{2}$ Department of Pharmacy, Kathmandu University, Nepal \\ Corresponding Author: Deepak Sharma and Janardan Lamichhane, Department \\ of Biotechnology, School of Science, Kathmandu University, Nepal.
}

Received: February 24, 2020

Published: March 09, 2020

(C) All rights are reserved by Deepak

Sharma., et al.

\begin{abstract}
Myrica esculanta (Kafal), is one of the most important native medicinal plant of Nepal which is domesticated for economic growth for the rural people. To authenticate and develop molecular database we collect samples all over Nepal. DNA barcodes can be used as reliable tools to facilitate the identification of medicinal plants for the safe use, important for metal absorption and value added products. In this study, investigation of Myrica esculanta for its molecular identification by DNA barcoding was done through sequence analysis with three barcode loci rbcL, matK and ITS genes, and found only first two are be the best for it authentication based on databased search on NCBI. The nucleotide sequence of internal transcribed spacers (ITS2) and chloroplast maturase kinase gene (matK) and rbcL have determined close relationship among 12 other species of Myrica|; to construct the phylogenetic tree. The phylogenetic relationships of accessions based on the matK and rbcL region showed that all accessions in this study were related to three geographical origins. Based on sequence alignment and phylogenetic analyses and comparative sequence analysis based on sequence based taxonomic parameter on iBOLD database, we concluded that the rbcL and matK sequences can distinguish $M$. esculanta accessions from iBOLD database.
\end{abstract}

Keywords: DNA Barcoding; Internal Transcribed Spacer; Maturase K; Phylogenetic; iBOLD

\section{Introduction}

The genus Myrica consists about 97 species of small tree and aromatic shrubs belonging to family Myricaceae. These are reported to be globally distributed in both temperate and sub-tropical regions of the world [1]. Kafal trees are found on hills of Nepal and Northern India, between the altitudes of one and two thousand meters above sea level. Kafal changes to reddish purple color ellipsoid-shape fruit at its maturity. In scientific journals, Kafal is mostly called Myrica esculenta, but also referred as Myrica integrifolia and Myrica nagi. In ancient Sanskrit language, Kafal is often called Kaiphala or Katphala and believed to have a medicinal property in its bark [1]. The bark is yellow colored and contains the chemical substances myricetin, myricitrin and glycosides [2,3]. M. esculenta is a small tree or large shrub native to Hills of Nepal and northern India. Its common names include Box myrtle, Bayberry, Kafal (local name) [2]. It is a well-known medicinal plant in Ayurveda or Himalayan Wild Fruit - Kathfal. Nepali name Kaaphal or Kafal Common name - Bay-Berry, Box myrtle. Kaaphal is one of many extremely delicious wild fruits found throughout mid-Himalayan region. The fruit looks somewhat like deep-red colored raspberries [4]. They barely have any pulp, have a big round seed in the center. Since they are very refreshing to eat, they are well liked by many Nepalese. The fresh fruits have a reputation for being a little acidic even when they are ripe, but more sour when unripe [5]. They have a limited harvesting period and available for a short period of time only. When they were in season, local villagers picked and gathered 
the berries carefully from the wild growing areas and transported to Kathmandu in a wicker baskets (doko-daalo). It is not a good timber as it warps and splits badly, but is used occasionally for lowgrade construction and, agricultural implements. In spite of being a multipurpose tree, the cultivation of the plant is very limited and most of the traditional and commercial uses of M. esculenta plant depend exclusively on the collections from the wild sources by indigenous people. Thus, the species is under imminent danger of extinction from wild sources due to increase in urbanization, over harvesting, negligence of sustainable utilization and over exploitation of forests and waste lands for commercial uses [6,7]. Poor regeneration in natural habitat due to high anthropogenic activity is another important factor, which affect the natural population of this plant species [8]. Screening of various Himalayan species of medicinal plants have been already done in Nepal [9], but lack the M. esculenta species with molecular based analysis is yet to perform.

Phylogeny reconstruction within closely related species may be difficult because of incomplete lineage sorting, introgression, short evolutionary scale, and lack of molecular markers in poorly studied taxa [10]. In this circumstance, reduced-representation genome sequencing methods allow us [11] to sequence the regions flanking restriction sites with deep coverage, then to align orthologous sequences across multiple samples to discover thousands of genetic markers for systematics, population genomics and adaptive evolution studies [12,13]. Sequence based analysis play important role in the study of species identification [14]. The phylogenic trees constructed to show the relatedness and distance of the analyzed plants in the history of evolution by the analysis of richness of clades. The construction of DNA barcode library of medicinal plants is an introductory research arena in Himalayan region of in helping the routine identification of plants [15], and developing guidelines for detection of adulterants in herbal medicines as well as protection of biodiversity conservation [16] and economic growth by value added product, production from plants fruits.

DNA Barcoding of M. esculenta in Nepal has not been yet reported with any barcode loci ITS (non coding region), rbcL nor even matK [17-19].
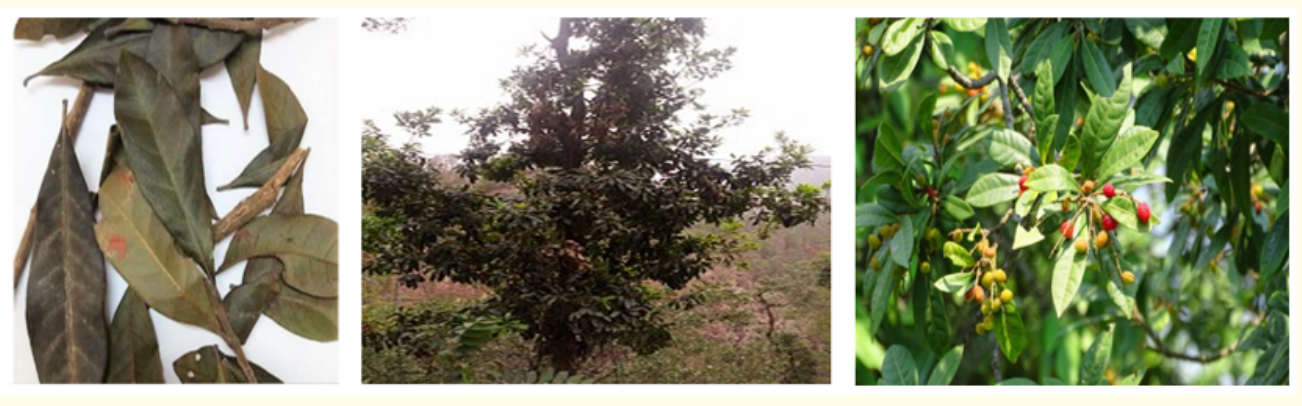

Figure 1: Leaf, Tree and Fruits of M. esculanta.

\section{Materials and Methods}

Study area

Collection of M. esculanta from three different location of Nepal was done in the month of May 2017 form Gulmi, Palpa and Kathmandu, three different geographical location as shown in figure 2 .

\section{Sample preparation}

The DNA was isolated using ZR Genomic DNATM-Tissue MiniPrep (Zymo Research, USA). According to the manufacturer's manual [2], Folmer region was amplified using MyTaqTM Red DNA Polymerase (BioLine, UK). The primers used for the amplification of the rbcL gene were rbcLa -F (forward ATGTCACCACAAACAGAGACTAAAGC and rbcLa -R (reverse GTAAAATCAAGTCCACCRCG ) and for matK-xF (forward) TAATTTACGATCAATTCATTC and matK-MALPR1 (reverse ACAAGAAAGTCGAAGTAT) table 1 . The thermal program consisted of initial step of 2 minutes at $54^{\circ} \mathrm{C}$ followed by 35 cycles of 40 seconds at $94^{\circ} \mathrm{C}, 40$ seconds at $55^{\circ} \mathrm{C}$ and 1 minute at $72^{\circ} \mathrm{C}$ followed in turn by final extension of 10 minutes at 
$72^{\circ} \mathrm{C}$. The PCR products were visualized on $1.2 \%$ agarose gels, purified and sequencing. Amplicons were purified using DNA Clean and Concentrator TM-25. Products were labelled using the BigDye Terminator V.3.1 Cycle sequencing kit (Applied Biosystems, Inc.) and sequenced bidirectionally using ABI 3730 Automated Sanger sequencer (Macrogen, Inc.). Sequence was evaluated, assembled, and aligned using Geneious V8.1 software and submitted to GenBank database. Refined sequence was used to identify the species using DNA related database (BOLD and BLASTn) Sequence Editing, Aligning, Assembly and Data Analysis
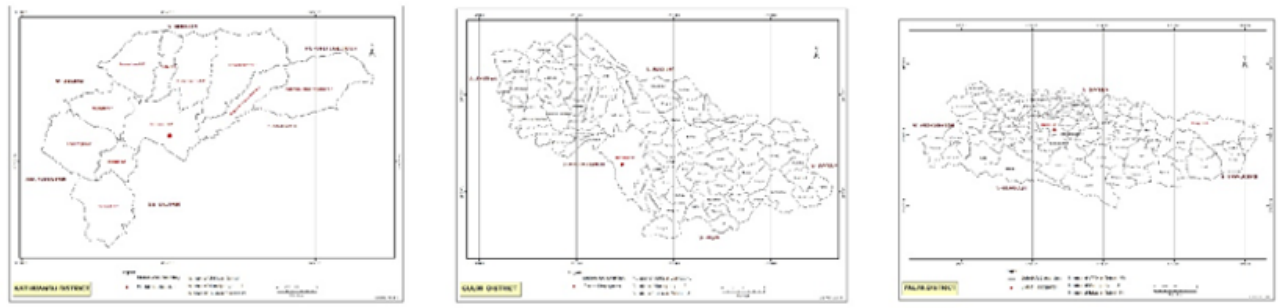

Figure 2: Sample collection area (Kathmandu, Gulmi and Palpa).

\begin{tabular}{|c|c|c|c|c|}
\hline $\begin{array}{l}\text { Barcode } \\
\text { genes }\end{array}$ & PCR Primers & Primer sequence 5' -3' & $\begin{array}{l}\text { Annealing Temp } \\
\text { for (PCR) }\end{array}$ & Sequencing Primers \\
\hline rbcL & rbcLa -F (forward & ATGTCACCACAAACAGAGACTAAAGC & $55^{\circ} \mathrm{C}$ & rbcLa $-F^{*}$ \\
\hline matK & \multicolumn{2}{|c|}{$\begin{array}{c}\text { matK-xF (forward) } \\
\text { TAATTTACGATCAATTCATTC }\end{array}$} & & $\begin{array}{c}\text { matK-xF } \\
\text { matK-MALPR1 (choice I)* } \\
\text { matK-1RKIM-f } \\
\text { matK-MALPR1 (choice II)* }\end{array}$ \\
\hline matK & \multicolumn{2}{|c|}{ ACCCAGTCCATCTGGAAATCTTGGTTC } & & matK-1RKIM-f* \\
\hline
\end{tabular}

Table 1: List of PCR primers and sequencing primers used in the DNA barcoding.

*Bidirectional Sequencing

\begin{tabular}{|l|c|c|c|}
\hline Reagents & rbcL $(\boldsymbol{\mu l})$ & matK $(\boldsymbol{\mu l})$ & Volume for unit reaction $(\mathbf{1 X})(\boldsymbol{\mu l})$ \\
\hline 10X Buffer & 20 & 20 & 2.0 \\
\hline $50 \mathrm{mM}$ MgCl2 & 3 & 3 & 0.3 \\
\hline $10 \mu \mathrm{M}$ Primer Forward & 2 & 2 & 0.2 \\
\hline $10 \mu \mathrm{M}$ Primer Reverse & 2 & 2 & 0.2 \\
\hline $10 \mathrm{mM}$ dNTPs & 2 & 2 & 0.2 \\
\hline DNA Polymerse $(5 \mathrm{U} / \mu \mathrm{l})$ & 1 & 1 & 1 \\
\hline DNA Template $(20-40 \mathrm{ng} / \mu \mathrm{l})$ & 10 & 10 & 10 \\
\hline ddH $_{2} \mathrm{O}$ & 60 & 60 & 60 \\
\hline Total Reaction volume & 100 & 100 & 100 \\
\hline
\end{tabular}

Table 2: Combinations and concentrations of reagents used for PCR reactions of rbcL , matK and ITS2 for analysis of $M$. esculanta 


\begin{tabular}{|l|c|c|c|c|}
\hline $\begin{array}{l}\text { Tempera- } \\
\text { ture }\end{array}$ & Time & Cycle & Function & $\begin{array}{c}\text { Annealing } \\
\text { Temp } \\
\text { for (PCR) }\end{array}$ \\
\hline $98^{\circ} \mathrm{C}$ & $45 \mathrm{sec}$ & & & $55^{\circ} \mathrm{C} \mathrm{rbcL}$ \\
\hline $98^{\circ} \mathrm{C}$ & $10 \mathrm{sec}$ & 35 & Denaturation & \\
\hline $59^{\circ} \mathrm{C}$ & $30 \mathrm{sec}$ & & Annealing & $59^{\circ} \mathrm{C}$ ITS \\
\hline $72^{\circ} \mathrm{C}$ & $40 \mathrm{sec}$ & & Extension & \\
\hline $72^{\circ} \mathrm{C}$ & $10 \mathrm{~min}$ & & Final extension & $56^{\circ} \mathrm{C}$ matK \\
\hline
\end{tabular}

Table 3: PCR Program for DNA amplification for all the 3 gene loci.

PCR and sequencing

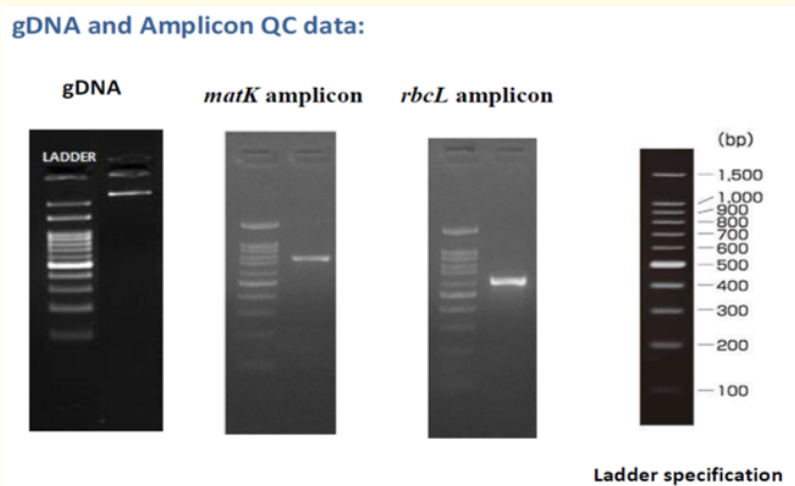

Figure 3: Genomic DNA, MatK gene and rbcL gene electrophoresis picture.

Sanger seq matK data

$>$ Kafal_data
GCGGTTCTTTCTTCATGAGTATTCTAATTGTAGCATTCGTATTATTCCAAAAAAAAACGAATCCATTTCTATTTTTTTAAAAAGTAATCCAAGATTATTGTTATTTTTATATAATTCTCATATATGTGAATACGAATCCGTCTTCTTTTTTATCCGTAACCAATCTTCTCATTTACGATTAACATCTTCTGGAGTCCTTTTTGAGCGAATCTATTTACATAGAAAAATGGAACATCTTGTCAAAGTCTTTGCTAATAATTTTCGGGGCATCCTATGCTTCCCGAAGGATCCTTTCATTCATTATGTTAGATATCAAGGAAAATCAATTCTGGTTTCAAAAGATACACCTCTTCTGATAAATAAATGGAAATAT TAC C T T GT CAAT T TAT GGCAAT GT CAT T T T TCTGT GT GGTCTCGCCTGGGAAGGATCTATATAAACCAATTAT CCAAGCATTCCCTCGACTTTTTGGGTTATTTTTCAAGTGTGCGACTAAATCCTACAATGGTGCGTAGTCAAATGCTAGAAAATTCATTTATAATCAAAAATGCTCCCAAGAAGCTCGATACAATAGTTCCAATTATTCCTCTGATTGGATCATTGGCTAAAGCGAAATT TTGTAACGCATTAGGG TATCCCATTAGTAAGCTGACTCGGGCCGATTTATCGGATTTTGATATTATCAATCGATTTGTGCGTATATGCAGAAATCTTTCTCATTATTACAGCGGATCTTCAAAAAAAAAGAGTATGTATCGAACAAA

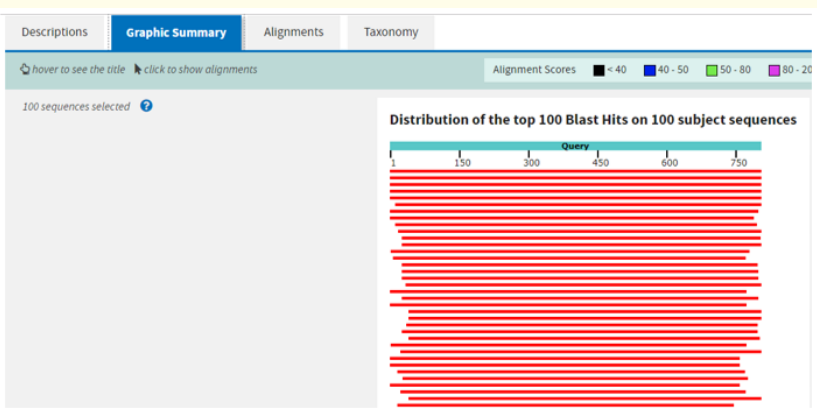

Figure 4: NCBI Blast output result show $100 \%$ similarity with M rubra sub species of $M$. esculanta with matK gene.

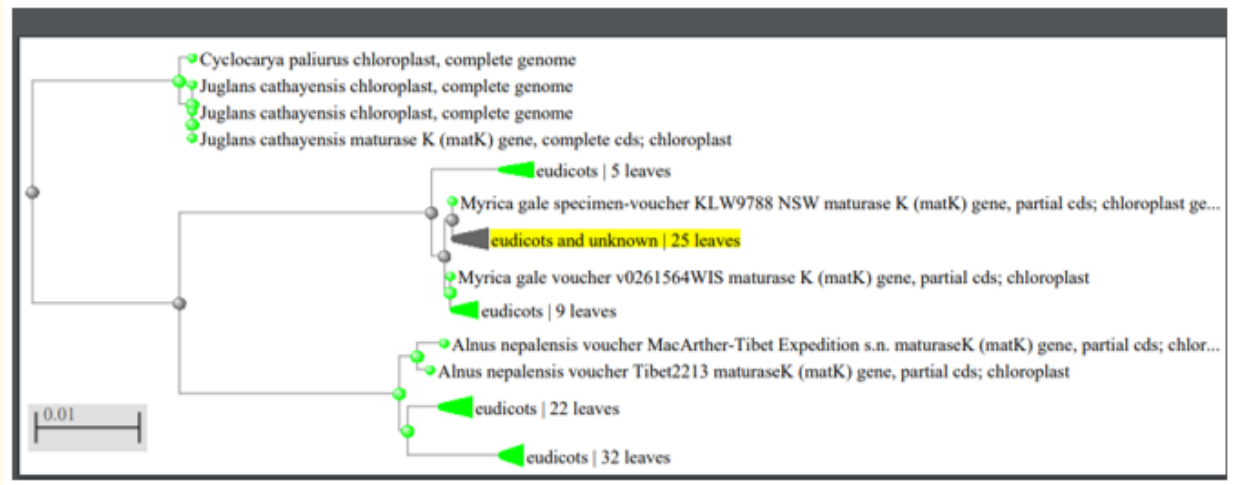

Figure 5: Phylogentics analysi of M. esculanta by NCBI, NJ method. 
Identification and comparison of barcodes sequence with ref-

erence to BOLD database:

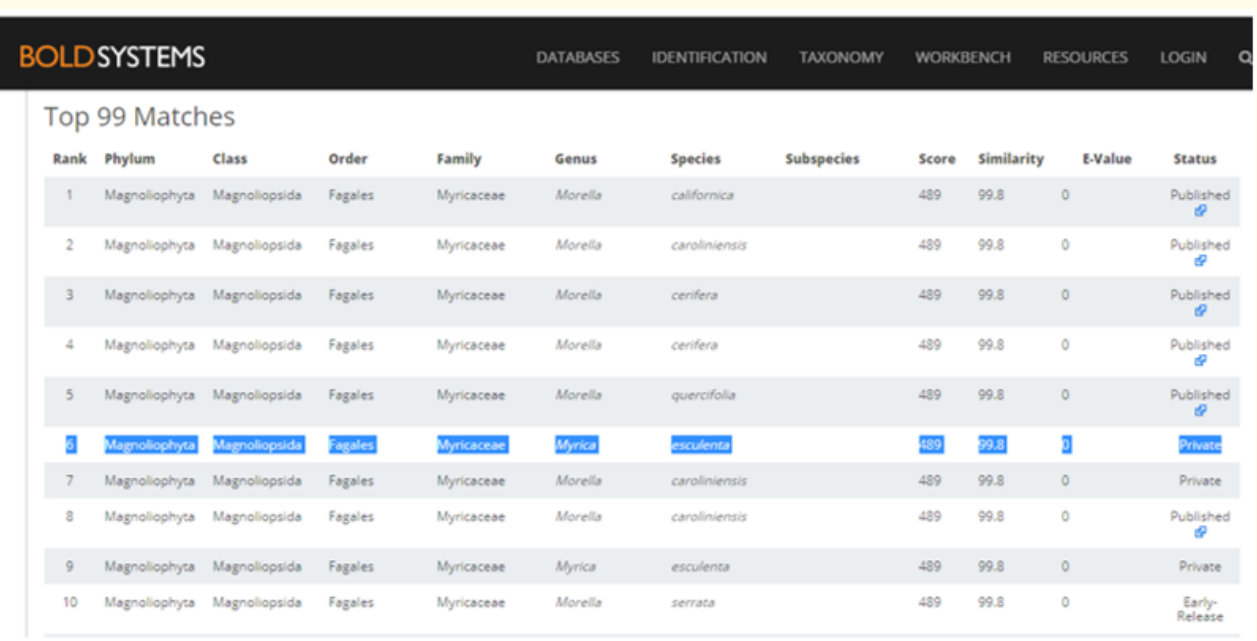

Figure 6: Sequence similarity with Bold database with rbcL gene.

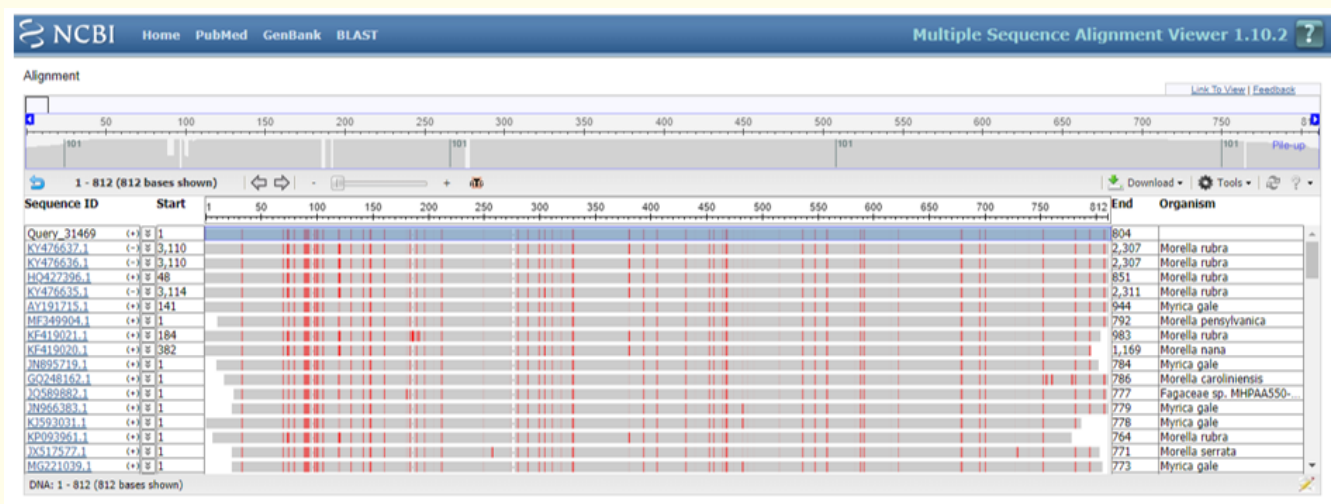

Figure 7: Sequence alignment result in NCBI data set for rbcL gene.

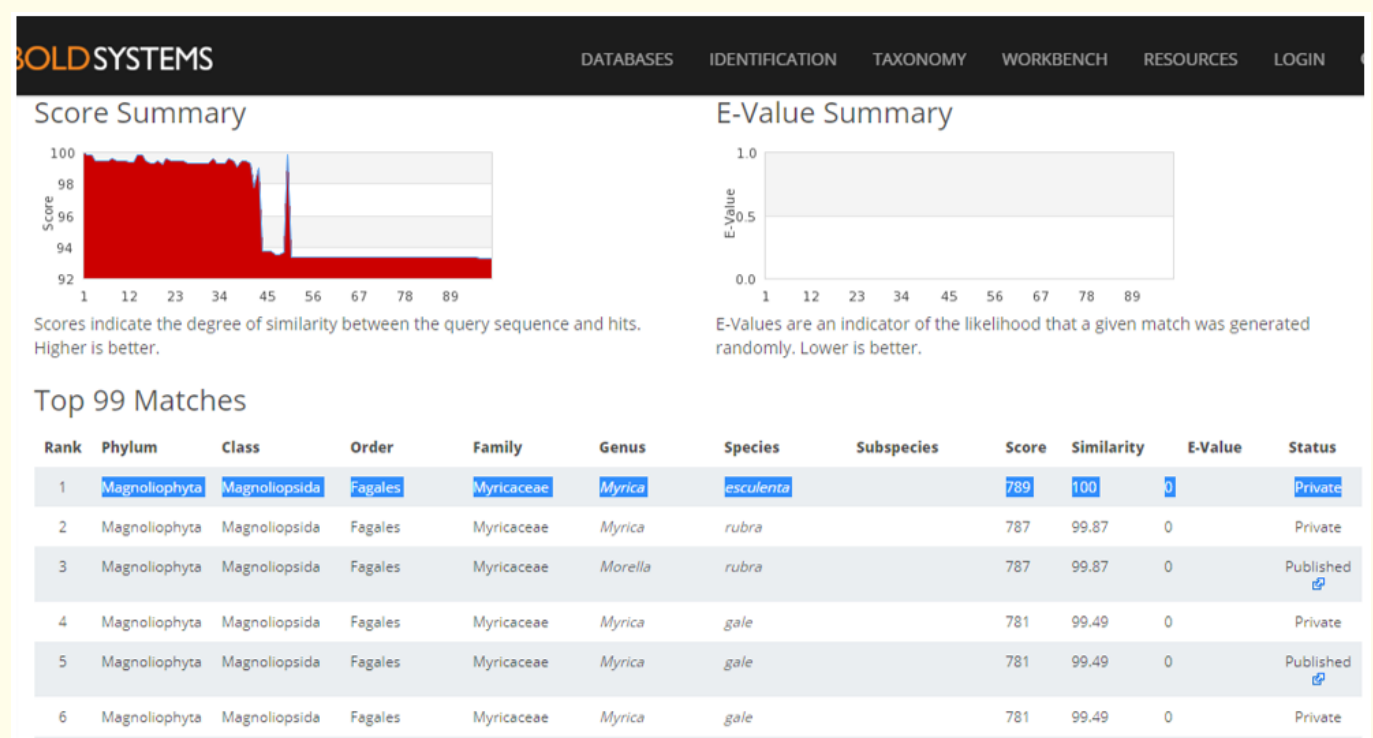

Figure 8: Sequence 100\% similarity with Bold database with MatK gene loci. 


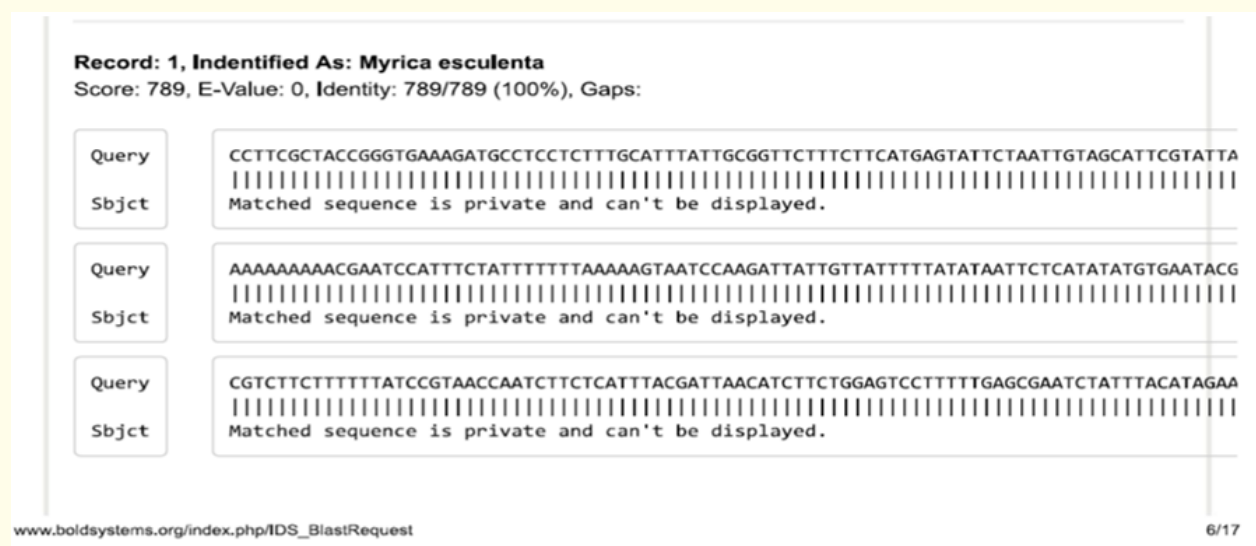

Figure 9: Identification of M. esculanta by matK gene in Barcode database.

Sequence Submitted to NCBI Database for Gi Number.

LOCUS Kafal_ 804 bp DNA linear 11-FEB-2020

DEFINITION data_MatK.

ACCESSION Kafal_

VERSION

\section{KEYWORDS.}

SOURCE chloroplast Myrica esculenta

ORGANISM Myrica esculenta

Unclassified.

REFERENCE 1 (bases 1 to 804)

AUTHORS Sharma,D. and Lamichhane,J.

TITLE DNA barcoding of Myrica esculanta (Kafal), An Indigenous, Multipurpose and Medicinal plant species from Nepal, by rbcL and matK gene

JOURNAL unpublished

REFERENCE 2 (bases 1 to 804)

AUTHORS Sharma,D. and Lamichhane,J.

TITLE Direct Submission

JOURNAL Submitted (11-FEB-2020) Biotechnology, Kathmandu University,

Dhulikhel, Kavre, Nepal, Dhulikhel, 3 Bagmati 44600, Nepal

COMMENT

Bankit Comment: ALT EMAIL:deepakshrm59@gmail.com

Bankit Comment: TOTAL \# OF SEQS:1
Bankit Comment: TAX: Yes, new species/combinations; SEE ATTACHMENT

\#\#Assembly-Data-START\#\#

Sequencing Technology :: Sanger dideoxy sequencing

\#\#Assembly-Data-END\#\#

FEATURES Location/Qualifiers

source $1 . .804$

/organism="Myrica esculenta"

/organelle="plastid:chloroplast"

/mol_type="genomic DNA"

/tissue_type="Plant Leaf"

/country="Nepal"

/altitude="1350 m."

/collected_by="Deepak Sharma"

/identified_by="Tirtha Maiya Shrestha"

BASE COUNT 242 a 147 c 126 g 289 t

ORIGIN

1 ccttcgctac cgggtgaaag atgcctcctc tttgcattta ttgcggttct ttcttcatga 61 gtattctaat tgtagcattc gtattattcc aaaaaaaaac gaatccattt ctattttttt 121 aaaaagtaat ccaagattat tgttattttt atataattct catatatgtg aatacgaatc 181 cgtcttcttt tttatccgta accaatcttc tcatttacga ttaacatctt ctggagtcct 241 ttttgagcga atctatttac atagaaaaat ggaacatctt gtcaaagtct ttgctaataa 
$301 \mathrm{ttt}$ cggggc atcctatgct tcccgaagga tcctttcatt cattatgtta gatatcaagg

361 aaaatcaatt ctggtttcaa aagatacacc tcttctgata aataaatgga aatattacct

421 tgtcaattta tggcaatgtc attttctgt gtggtctcgc ctgggaagga tctatataaa 481 ccaattatcc aagcattccc tcgacttttt gggttatttt tcaagtgtgc gactaaatcc 541 tacaatggtg cgtagtcaaa tgctagaaaa ttcatttata atcaaaaatg ctcccaagaa

601 gctcgataca atagttccaa ttattcctct gattggatca ttggctaaag cgaaattttg 661 taacgcatta gggtatccca ttagtaagct gactcgggec gatttatcgg attttgatat

721 tatcaatcga tttgtgcgta tatgcagaaa tctttctcat tattacagcg gatcttcaaa 781 aaaaagagt atgtatcgaa caaa

\section{Results and Discussion}

M. esculenta is a multipurpose potent income generating species of Nepalese Himalaya. The species is in the verse of extinction from wild due to overexploitation by the indigenous people as well as poor regeneration of the species in their natural habitat. Immediate scientific intervention and some preliminary necessary action should be taken for the multiplication and establishment of the species in their natural habitat.

\section{Phylogeny Study}

The comparative analysis of molecular sequence data is essentially important for reconstructing evolutionary history of plants. The discriminatory influence of three barcode genes [20]. ITS, rbcL and matK was considered in pairwise distance matrix to construct phylogenetic tree using in MEGA X software [21]. The evolutionary history was inferred using pairwise distances in Maximum Composite Likelihood (MCL) [22]. The phylogenetic relatedness and evolutionary history drown by means of neighbor-Join (NJ) method [23] using nucleotide sequence alignment of rbcLa [24] and ITS2 [25] and matK [26] (Figure 2 and Figure 3). The evolutionary distance analysis conducted using Kimura 2-parameter [27] method of base substitution per site and mentioned by units. The pairwise distance matrix value indicates their closeness during evolution and ultimately helps to draw their phylogenetic tree and the history of evolution. The clades formed in the trees were mostly mixture of several plant species and the big and small branches showed their relatedness and distances clearly among the plant species [5].

\section{Acknowledgements}

The research part of this project has been supported by UGCNepal Faculty Grant 2017 and publication support by NAST PhD Grant 2014.

\section{Conflicts of Interest}

The authors declare no conflict of interest.

\section{Bibliography}

1. Yanthan M and Misra A. "Molecular approach to the classification of medicinally important actinorhizal genus Myrica". Indian Journal of Biotechnology 12 (2013): 133-136.

2. SHRI. PSAR. <a-review-on-ethnomedicinal-phytochemicaland-pharmacological-aspects-of-imyrica-esculentai.pdf $>$.

3. Shin T., et al. "Traditional knowledge of wild edible plants with special emphasis on medicinal uses in Southern Shan State, Myanmar". Journal of Ethnobiology and Ethnomedicine 14 (2018): 48.

4. Heinrich $\mathrm{M}$ and Anagnostou S. "From Pharmacognosia to DNA-Based Medicinal Plant Authentication - Pharmacognosy through the Centuries". Planta Medica 83 (2017): 1110-1116.

5. Kabra A., et al. "Pharmacognostic characterization of Myrica esculenta leaves". Journal of Ayurveda and Integrative Medicine 10 (2019): 18-24.

6. Srivastava B., et al. "Evaluation for substitution of stem bark with small branches of Myrica esculenta for medicinal use A comparative phytochemical study". Journal of Ayurveda and Integrative Medicine 7 (2016): 218-223.

7. Ksanbok <Ksanbok.pdf $>$.

8. Singh, Y. <Yogendra Singh Myrica_esculenta_wild_edible_fruit_ of_In.pdf>. Eco. Env. and Cons. (2016): (S267-S270).

9. Sharma D., et al. "Screening and bioactivity measurement of high altitude medicinal plants of Nepal". Vegetos- An International Journal of Plant Research 29 (2016).

10. Cariou M., et al. "Is RAD-seq suitable for phylogenetic inference? An in silico assessment and optimization". Ecology and Evolution 3 (2013): 846-852.

11. Elshire RJ., et al. "A robust, simple genotyping-by-sequencing (GBS) approach for high diversity species". PLoS One 6 (2011): e19379-e19379. 
12. Miller MR., et al. "Rapid and cost-effective polymorphism identification and genotyping using restriction site associated DNA (RAD) markers". Genome Research 17 (2007): 240-248.

13. Baird NA., et al. "Rapid SNP discovery and genetic mapping using sequenced RAD markers". PLoS One 3 (2008): e3376e3376.

14. Aziz NAA., et al. "Molecular DNA identification of medicinal plants used by traditional healers in Malaysia". Genetics and Molecular Research 14 (2015): 15937-15947.

15. Ratnasingham S and Hebert PDN. "Bold: The Barcode of Life Data System (http://www.barcodinglife.org)". Molecular Ecology Resources 7 (2007): 355-364.

16. Umdale SD., et al. "Molecular Authentication of the Traditional Medicinal Plant "Lakshman Booti" (Smithia conferta Sm.) and Its Adulterants through DNA Barcoding". Pharmacognosy Magazine 13 (2017): S224-S229.

17. Yang S., et al. "Application of phylogenetic information of ITS2 secondary structure in DNA barcoding of Solanum medicinal plant". Zhongguo Zhong Yao Za Zhi 42 (2017): 456-464.

18. Zhang J., et al. "Evaluation of four commonly used DNA barcoding Loci for chinese medicinal plants of the family schisandraceae". PLoS One 10 (2015): e0125574-e0125574.

19. Pedales RD., et al. "DNA Barcoding of Philippine Herbal Medicinal Products". Journal of AOAC International 99 (2016): 1479-1489.

20. Hollingsworth PM., et al. "A DNA barcode for land plants". Proceedings of the National Academy of Sciences 106 (2009): 12794-12797.

21. Kumar S., et al. "MEGA7: Molecular Evolutionary Genetics Analysis Version 7.0 for Bigger Datasets". Molecular Biology and Evolution 33 (2016): 1870-1874.

22. Kumar S., et al. "MEGA: A biologist-centric software for evolutionary analysis of DNA and protein sequences". Briefings in Bioinformatics 9 (2008): 299-306.

23. Saitou N and Nei M. "The neighbor-joining method: a new method for reconstructing phylogenetic trees". Molecular Biology and Evolution 4 (1987): 406-425.

24. Gielly L and Taberlet P. "The use of chloroplast DNA to resolve plant phylogenies: noncoding versus rbcL sequences". Molecular Biology and Evolution 11 (1994): 769-777.
25. Schoch CL., et al. "Nuclear ribosomal internal transcribed spacer (ITS) region as a universal DNA barcode marker for $<\mathrm{em}>$ Fungi</em>". Proceedings of the National Academy of Sciences 109 (2012): 6241-6246.

26. Barthet MM and Hilu KW. "Expression of matK: Functional and Evolutionary Implications". American Journal of Botany 94 (2007): 1402-1412.

27. Edgar RC. "MUSCLE: multiple sequence alignment with high accuracy and high throughput". Nucleic Acids Research 32 (2004): 1792-1797.

\section{Assets from publication with us}

- Prompt Acknowledgement after receiving the article

- Thorough Double blinded peer review

- Rapid Publication

- Issue of Publication Certificate

- High visibility of your Published work

Website: https://www.actascientific.com/

Submit Article: https://www.actascientific.com/submission.php Email us: editor@actascientific.com

Contact us: +919182824667 